Педагогіка

УДК 373.29

Бандура Альона Валентинівна

магістрантка факультету іноземних мов

Ніжинського державного університету імені Миколи Гоголя

\title{
ФОРМУВАННЯ КОМПЕТЕНТНОСТІ В АНГЛОМОВНОМУ АУДІЮВАННІ УЧНІВ СТАРШОЇ ШКОЛИ ЗАСОБАМИ ІНТЕРНЕТ ПОДКАСТІВ PODCASTSINENGLISH.COM
}

Анотація. У статті проаналізовано етапи формування компетентності в англомовному аудіюванні учнів старших класів $i$ запропоновано методику залучення Інтернет подкастів. Показано, щуо робота з подкастом організовується у три етапи: дотекстовий, супровідний і післятекстовий.

Ключові слова: компетентність, англомовне аудіювання, Інтернет подкаст, дотекстовий етап, супровідний етап, післятекстовий етап.

Постановка проблеми. Аудіювання $\epsilon$ органічною складовою навчального процесу і невід’ємним компонентом усного мовлення, однак у процесі формування іншомовної компетентності учнів значна увага надається говорінню i лише незначна частина навчального часу відводиться на аудіювання. Аудіювання є самостійним видом мовленнєвої діяльності, оскільки нормативне говоріння учнів безпосередньо залежить від рівня сформованості іншомовної компетентності в аудіюванні.

У навчальному процесі 3 IM аудіювання виконує низку функцій. Передусім аудіювання виступає самостійним видом іншомовної мовленнєвої діяльності, наприклад, слухання оголошень, лекцій, доповідей, радіо- і телепередач, співрозмовника по телефону, виступів акторів тощо. Водночас аудіювання входить до складу діалогічного 
мовлення [6, с. 130]. У навчальному процесі з IM у СН3 аудіювання $є$ також засобом навчання, наприклад, при поясненні вчителем нового матеріалу, наданні настанови до виконання вправ тощо.

Аналіз останніх досліджень і публікацій. Палітра доробку вітчизняних науковців, які працюють над проблемами навчання аудіювання, дуже різнопланова. Її характеризують дослідження О. Б. Бігич (методика формування іншомовної компетентності в аудіюванні), С. В. Гапонової (навчання розуміння аудіотекстів учнів старших класів середньої школи), I. А. Круківської (використання пісень у процесі навчання аудіювання), І. П. Лисовець (інтегроване навчання аудіювання та усного мовлення), О. Б. Метьолкіної (використання ігор для навчання аудіювання молодших школярів), С. Ю. Ніколаєвої і О. П. Петращук (тестовий контроль аудитивних умінь), А. Г.Неділько (застосування автентичних матеріалів для навчання іноземних мов), Н. В. Харченко (аудіювання як вид мовленнєвої діяльності дітей дошкільного віку) та ін.

Водночас актуальність проблеми формування іншомовної компетентності в аудіюванні зумовлюється потребою ii дослідження 3 урахуванням інтересів сучасної молоді. Сучасні молоді люди багато часу проводять в інтернеті, а тому використання різних інтернет-ресурсів $\epsilon$ доцільним для формування іншомовної комунікативної компетентності. Інтернет подкасти можуть зокрема бути ефективним засобом формування компетентності в аудіюванні.

Метою роботи $\epsilon$ створення науково обгрунтованої та перевіреної шляхом пробного навчання методики формування компетентності в англомовному аудіюванні учнів старшої школи засобами інтернет подкастів Podcastsinenglish.com.

Виклад основного матеріалу. Аудіювання визначається як внутрішній, реактивний, рецептивний вид мовленнєвої діяльності, що 
належить до усного мовлення і грунтується на механізмах сприймання та розуміння мовлення на слух [6, с. 130].

Компетентність в аудіюванні (КА) є здатністю слухати й розуміти автентичні тексти різних жанрів i видів в умовах прямого й опосередкованого спілкування. До прямого аудіювання відносять діалогічне спілкування в реальній ситуації, до опосередкованого - теле- й радіомовлення [2, с. 11]. Компетентність в аудіюванні включає в себе чотири складники: 1) вміння, 2) навички, 3) знання, а також 4) комунікативні здібності. До основних чинників, що зумовлюють успішність формування КА відносять: 1) умови сприймання аудіоповідомлення; 2) індивідуальні психологічні особливості слухача; 3) мовні характеристики аудіо повідомлення [2, с. 19].

Зміст формування комунікативної компетентності загалом та компетентності в аудіюванні зокрема визначено у документі «Загальноєвропейські Рекомендації з мовної освіти: вивчення, викладання, оцінювання» [7]. Це керівний документ, який використовується для опису досягнень осіб, що вивчають іноземні мови в Європі. Рекомендації $є$ результатом роботи колективу спеціалістів, задіяних у навчанні й викладанні іноземних мов, упродовж 20 років - 3 початку 1980-х років і до 2001 року, коли Рада Європи рекомендувала використання цього документу для валідації рівнів знань іноземної мови. Разом $з$ тим, робота над вдосконаленням цього документу триває і далі і у 2018 році Рада затвердила додаток до Рекомендацій під назвою Companion Volume with New Descriptors [1].

Ключовим положенням цих документів $є$ те, що мова розглядається не як самоціль, а як засіб для досягнення різних соціальних, освітніх та професійних цілей. Компетентність користувача визначається за допомогою категорій A, B, C, кожна з яких має свої властивості, названі дескрипторами. Кожна категорія включає два рівні, що показують прогрес 
у розвитку компетентності: категорія $\mathbf{A}$ (Елементарний користувач) включає рівні A1 Інтродуктивний та A2 Середній, В (Незалежний користувач) передбачає рівні В1 Рубіжний та В2 Просунутий i C (Досвідчений користувач) включає рівні С1 Автономний та С2 Компетентний. Передбачається, що учень здатен писати, слухати, говорити та читати на кожному з рівнів [1].

Відповідно до Рекомендацій та додатку 2018 року, учні старшої школи (10-11 класи) спрямовані на досягнення рівня В1 за стандартної підготовки в загальноосвітньому навчальному закладі чи рівня В2 за умови профільної підготовки. Щодо рівня В1, учень здатен зрозуміти фактичну інформацію про звичайні щоденні або пов'язані з певною діяльністю теми, сприймаючи як загальні повідомлення так і конкретні деталі, якщо мова чітко сформульована в загальновизнаному акценті. Учень може зрозуміти основні положення чіткої стандартної вимови на знайомі речі, що регулярно зустрічаються в роботі, в школі, дозвіллі тощо.

На рівні В2 учень може розуміти стандартну розмовну мову, живу або трансльовану чи в аудіо записі як на знайомі, так і нові теми, з якими зазвичай стикаються в особистому, соціальному, або професійному житті. Лише сильний фоновий шум, неадекватна структура дискурсу та/або специфічне ідіоматичне використання впливає на здатність розуміти тексти. Учень також може зрозуміти основні ідеї на конкретні, так і на абстрактні теми за стандартної вимови, включаючи дискусії у певній галузі спеціалізації [1].

Вимоги до вправ для формування компетентності в англомовному аудіюванні засобами інтернет подкастів. Застосування інформаційних технологій, зокрема подкастів, у навчанні англійської мови учнів старшої школи дозволяє зробити процес вивчення мови ефективнішим, прогресивнішим та цікавішим, однак специфіка подкастів 
передбачає нові вимоги до вправ, які вчитель застосовує для формування компетентності учнів.

Передусім учитель визначає мету застосування подкастів: повторення пройденого матеріалу чи введення нового. Для повторення пройденого матеріалу (repetitive) подкаст може використовуватися на початку уроку для створення сприятливої мовної атмосфери для подальшої роботи («warm-up») або під кінець заняття, щоб вивести матеріал у загальне обговорення i стимулювати обмін думками та ідеями у непідготовленому мовленні. Для введення нової додаткової інформації (supplemental) подкасти використовується безпосередньо перед введенням нових лексичних або граматичних явищ для їх первинної презентації. Наприклад, прослуховуючи інтерв’ю, різні додаткові аудіофрагменти 3 певної тематики, радіопрограми, оголошення тощо, учні вперше стикаються 3 новими мовними одиницями, а далі натреновують їх [4, c. 52].

Подкаст доцільно слухати двічі, чим більше разів учень слухає подкаст, тим швидше він звикає до вимови та інтонації носія мови та розуміє суть. Подкасти можна використовувати і для індивідуального тренування швидкості мовлення через просту вправу - імітувати тембр, інтонацію та швидкість мови диктора, намагаючись повторити за ним його виступ [3].

У цілому робота 3 подкастом збігається 3 технологією роботи над звичайним аудіо текстом, включаючи такі етапи роботи: попередній інструктаж i завдання; процес сприйняття й розуміння інформації подкасту; завдання, котрі контролюють розуміння почутого тексту. Добираючи чи розробляючи вправи до подкастів, спрямовані на формування навичок сприймання на слух і розвиток умінь аудіювання, слід ураховувати рівні складності різних типів завдань [6, с. 131]. 
Так, для відпрацювання усного мовлення при роботі з подкастами можна використовувати діалогові аудіо- чи відеофрагменти, після прослуховування / перегляду котрих викладач ставить завдання передати письмово почуте (тобто, по суті, створити скрипт). Створивши власний скрипт i звіривши його 3 оригіналом, можна попрацювати 3 лексикою (словами), зробити літературний переклад уривку, що забезпечує пасивне запам’ятовування слів унаслідок багаторазового звертання до них [22].

Подкасти ресурсу Podcastsinenglish.com $€$ цінними в аспекті дидактичних характеристик. По-перше, вони є доступними широкому загалу користувачів з можливістю скачування аудіо текстів. По-друге, всі подкасти містять автентичні матеріали, озвучені носіями мови. По-третє, вони є інформативними та актуальними, адже містять цікаву й сучасну інформацію про події, подорожі до країн, життєвий досвід, інновації тощо, що, беззаперечно, сприятиме підтриманню мотивації до вивчення англійської мови. Четвертою перевагою $є$ забезпечення компетентності в усіх видах мовленнєвої діяльності. I насамкінець їхня автономність. Як зазначають О.В. Давиденко і О.В. Пономаренко, «за допомогою новітніх методів, технологій, активних форм роботи створюється освітнє середовище, що дозволяє підтримувати мотивацію; стимулювати ініціативу; створювати ситуації творчого пошуку, вільного вибору, прийняття відповідальних рішень; здійснювати самоуправління та самоконтроль» $[5$, с. 44$]$.

Висновки. Робота 3 подкастом організовується у три етапи: установчий (передтекстовий), супровідний (текстовий) i післятекстовий. Метою дотекстового етапу $\epsilon$ введення учнів у контекст подкасту, активізація фонових знань із теми, що обговорюється, усунення можливих мовних труднощів, прогнозування змісту та мотивування до прослуховування, а отже, полегшення у сприйманні та інтерпретації запропонованого матеріалу. На текстовому етапі пропонуємо учням 
завдання, які активізують розумову активність під час слухання. На післятекстовому етапі пропонуємо вихід у ситуацію з непідготовленого мовлення. вправи цього етапу $є$ комунікативними та мають на меті інтегрувати отриману під час прослуховування подкасту інформацію у виконання іншої мовленнєвої діяльності, а саме говоріння, читання чи письма.

\section{Література}

1. Common European Framework of Reference for Languages: learning, teaching, assessment. Companion Volume with new descriptors. Strasbourg: Council of Europe, 2018. - 235 p.

2. Podcasts in higher education : students' and lecturers' perspectives [Електронний ресурс]. http://repositorium.sdum.uminho.pt/handle/1822/10080

3. Бігич О.Б. Методика формування іншомовної компетентності в аудіюванні / О.Б. Бігич // Іноземні мови. - 2012. - №2 (70). - С. 19-30.

4. Грітченко I. А. Використання Інтернет-технологій у процесі підготовки майбутніх учителів іноземної мови у ВНЗ / І. А. Грітченко - Умань: СПД Жовтий, 2014. - 72 с.

5. Давиденко О. В. Подкастинг як засіб формування компетентності в англомовному аудіюванні студентів молодших курсів / O.В. Давиденко, О.В. Пономаренко // ScienceRise: Pedagogical Education. 2018. - № 5 (25). - C. 43-46.

6. Методика навчання іноземних мов у загальноосвітніх навчальних закладах / [Л. С. Панова, І. Ф. Андрійко, С. В. Тезікова та ін.]. - К. : ВЦ «Академія», 2010. - 328 с.

7. Загальноєвропейські Рекомендації 3 мовної освіти : вивчення, викладання, оцінювання / наук. ред. укр. вид. проф. С.Ю. Ніколаєва. К. : Ленвіт, 2003. -273 с. 